\title{
Groundwater-Mixing Mechanism in a Multiaquifer System Based on Isotopic Tracing Theory: A Case Study in a Coal Mine District, China
}

\author{
Pinghua Huang $\mathbb{D}^{1,2}$ and Xinyi Wang $\mathbb{D}^{1,2}$ \\ ${ }^{1}$ School of Resources and Environment Engineering, Henan Polytechnic University, Jiaozuo 454000, China \\ ${ }^{2}$ Collaborative Innovation Center of Coalbed Methane and Shale Gas for Central Plains Economic Region, Henan Province, \\ Jiaozuo 454000, China
}

Correspondence should be addressed to Pinghua Huang; hph2001@hpu.edu.cn and Xinyi Wang; wangxy@hpu.edu.cn

Received 3 January 2018; Revised 27 April 2018; Accepted 4 June 2018; Published 9 July 2018

Academic Editor: Carmine Apollaro

Copyright (c) 2018 Pinghua Huang and Xinyi Wang. This is an open access article distributed under the Creative Commons Attribution License, which permits unrestricted use, distribution, and reproduction in any medium, provided the original work is properly cited.

\begin{abstract}
Water inrush of mixed groundwater is the primary threat against safe production in coal mines. To study the mixing mechanism of a multiaquifer groundwater system, groundwater samples were collected from different strata in a typical North China-type coalfield (Chaochuan Coal Mine) and were then tested using environmental isotopes $\left({ }^{18} \mathrm{O},{ }^{2} \mathrm{H},{ }^{3} \mathrm{H},{ }^{13} \mathrm{C}\right.$, and $\left.{ }^{14} \mathrm{C}\right)$ and hydrochemical ions $\left(\mathrm{Ca}^{2+}, \mathrm{Mg}^{2+}, \mathrm{Na}^{+}, \mathrm{K}^{+}, \mathrm{HCO}_{3}{ }^{-}, \mathrm{SO}_{4}{ }^{2-}\right.$, and $\left.\mathrm{Cl}^{-}\right)$as tracer agents. Results demonstrate that $\mathrm{HCO}_{3}^{-}$and $\mathrm{Cl}^{-}$ exhibit a linear relationship with the mixing ratio, whereas $\mathrm{Na}^{+}, \mathrm{Ca}^{2+}$, and $\mathrm{SO}_{4}{ }^{2-}$ show certain degrees of curvature. This condition indicates that groundwater mixing involves major chemical actions. The $\delta \mathrm{D}-\delta^{18} \mathrm{O}$ plot reveals that karst water and groundwater from Quaternary and sandstone aquifers are mainly mixtures of local rainfall, evaporated groundwater, and "palaeo-groundwater." The ${ }^{3} \mathrm{H}<0.5 \mathrm{TU}$ and ${ }^{14} \mathrm{C}$ content in the groundwater sample number 27 is $13.6 \mathrm{pmc}$, which suggests that this groundwater sample is the last rainfall recharge in the ice stage. Palaeo-groundwater in a sandstone aquifer accounts for more than $60 \%$, and that in the Cambrian limestone aquifer is lower than $20 \%$. Groundwater from the Quaternary aquifer is supplied by "modern" rainfall. The $\delta^{13} \mathrm{C}$ of groundwater from a sandstone aquifer decreases with the increase in $\mathrm{CO}_{3}{ }^{2-}+\mathrm{HCO}_{3}^{-}$, and this condition reflects that organic matters exhibit biological degradation reaction. However, $\delta^{13} \mathrm{C}$ increases with the rise in $\mathrm{CO}_{3}{ }^{2-}+\mathrm{HCO}_{3}{ }^{-}$in the Cambrian limestone groundwater, and this condition indicates that organic matters produce methane due to methanogens.
\end{abstract}

\section{Introduction}

Limestones are generally hidden directly below the Quaternary system of unconsolidated sediments in North Chinatype coalfields. Thus, they may cause vertical hydraulic connections between karst water and shallow groundwater. The gradual longitudinal advancement in coal exploitation has made hydrogeological conditions in mines increasingly complicated. Long-term water filling after exploitation may also destroy the original groundwater circulation in aquifers and intensify the mixing effect. Groundwater inrush occurs frequently, which prevents exploitation of abundant explored coal resources. Therefore, studying the groundwater-mixing process in coalfields during exploitation is extremely important.

Isotope geochemistry presents unique advantages in studying groundwater movement and has developed rapidly. It can extract useful information of water circulation and is free from restrictions of water content [1-19]. For example, stable water isotopes $\left({ }^{18} \mathrm{O},{ }^{2} \mathrm{H}\right.$, and $\left.{ }^{3} \mathrm{H}\right)$ can be used as conservative natural tracer agents in a hydrological environment and provide a new perspective for groundwater circulation. They not only can trace the movement mode and process of groundwater but also can disclose the inner link profile of unsaturated water with surface and ground water. Apart from stable isotopes such as $\mathrm{H}$ and $\mathrm{O}, \mathrm{T}$ and ${ }^{14} \mathrm{C}$ are also 
two important and powerful radioactive tracers [19]. They can be used to recognize modern and submodern rainfall recharges. They have been proven to be very useful in estimating recharging characteristics [20], correcting groundwater model [15], and examining regional groundwater movement [10]. $\mathrm{T}$ is used to estimate the mixing ratio of modern and submodern water in shallow aquifers and investigate the mixing process of groundwater [6]. Water movement rate and retention time can also be explored by recognizing the ${ }^{3} \mathrm{H}$ peak value $[16,17]$. Tenalem et al. studied the correlation between surface water and groundwater in the Awash River Basin by using environmental isotopes and water chemistry method and examined the flowing mode of groundwater by considering the local geological background. The isotope method has been widely used to analyze sources of groundwater, altitude of supply regions, and relative proportions of different supply sources [21]. Lima et al. explored environmental isotope features and groundwater sources in an aquifer in the Recife Coastal Plain in Brazil [22]. The isotope analysis results showed that groundwater includes three parts, namely, latest recharged groundwater, old evaporated groundwater, and saline water. Vengosh et al. investigated groundwater sources of a sandstone aquifer in Nubia, Israel [23]. The unique isotopic features and deuterium excess value demonstrate that groundwater has various supply sources. Murad examined the variation process of groundwater hydrogen and oxygen isotopes between the Oman Gulf and the Arabian Gulf [24]. He concluded that rainfall is the main supply source of groundwater, water vapor of rainfall comes from the Mediterranean, and rainfall evaporates before recharging to groundwater.

This study aims to evaluate the mixing characteristics of various types of groundwater and to determine the sources of groundwater and its mixing mechanism in the main water inrush aquifers under an environment where the degree of coal mining is becoming increasingly serious. This study also aims to provide a theoretical conclusion and lay a foundation for judging the source of water inrush.

\section{Hydrogeological Conditions}

The Chaochuan Coalfield lies between the North Asian and South Asian belts in the east section of the latitudinal structure in the Qinling Mountains. The coalfield is an arc uniclinal structure, with the arc top orienting to the south. The east wing formation extends toward the northeast and leans to the northwest, with a dip angle of approximately $20^{\circ}$. The west wing formation extends toward the northwest and leans to the northeast. The dip angle of strata is generally larger than $70^{\circ}$, accompanied with local upright or inverted strata. Complicated structures are also present in the region. The study region is mainly developed with a northwest-trend fault and a northeast-trend fault, which constitute the mine plot or boundaries of the coalfield. Faults control and influence the hydrogeological conditions in the study area in different degrees. An arc normal fault is developed at the north boundary in the study area. The fault is higher than $1000 \mathrm{~m}$. A karst-fractured aquifer is buried deeply below the Quaternary strata in the north of the fault, thereby forming water-blocking boundaries. A fault is present in the east boundary and also blocks water. Cambrian limestone is exposed in the southwest and south regions as belts and acts as the karst water recharge area (Figure 1). The groundwater usually flows from west to east and from south to north. In the study area, groundwater is generally discharged from the mine wells to the surface. Cambrian karst, Permian sandstone, and Quaternary aquifers are main aquifers in the study area. The Cambrian karst aquifer is developed with karst and has the strongest water among others. It is also the main water inrush aquifer at the coal seam floor because of its high hydraulic pressure and abundant recharge sources.

The Quaternary aquifer is of the Quaternary age and is composed of sands and gravels with a general thickness of $20-55 \mathrm{~m}$, and it generates water inflows of $15-50 \mathrm{~m}^{3} / \mathrm{h}$. The coal-bearing sandstone aquifer comprises sandstone, siltstone, and shale layers with permeability $(\mathrm{K})$ of 0.0178 $0.0594 \mathrm{~m} / \mathrm{d}$. This aquifer is in turn underlain by a Cambrian karst aquifer, which is the most important aquifer in the area. The latter aquifer has a thickness of approximately $250 \mathrm{~m}$ and is mainly composed of dolomitic, gray, and dark-gray limestones with permeability $(\mathrm{K})$ of $0.137-14.3 \mathrm{~m} / \mathrm{d}$. This aquifer has well-developed karst features.

The study area belongs to a semiarid continental monsoon climate region. The annual average precipitation is $668.1 \mathrm{~mm}$. Uneven rainfall distribution is observed among four seasons. Most precipitation occurs in July, August, and September and accounts for $50 \%-60 \%$ of annual precipitation. The evaporation is three times of precipitation, and the annual average evaporation is $1834 \mathrm{~mm}$. The annual average air temperature is $14.2^{\circ} \mathrm{C}$ (1957-2002). The Chaochuan River, which is the primary river in the study area, flows from southwest to northwest. River flow is controlled by atmospheric rainfall. The Chaochuan Reservoir is constructed in the middle stream of the Chaochuan River. The control basin area is $21 \mathrm{~km}^{2}$, and the effective reservoir capacity is $1,500,000 \mathrm{~m}^{3}$. The Chaochuan Reservoir is built in the limestone-exposed region. The surrounding areas are highly developed with surface and underground karsts. A large karst cave is present (Figure 1(a)), and Cambrian limestone is hidden directly below the Quaternary unconsolidated sediments (Figure 1(b)). The karst water can exhibit vertical hydraulic correlation with groundwater in a Quaternary aquifer.

\section{Materials and Methods}

3.1. Sample Collection and Testing. The 37 groups of water samples collected from the study area in August 2016 and October 2016 mainly include surface water and groundwater (Figure 1). Cambrian limestone groundwater samples were collected by stratification sampling at leakage points under the shaft, mixed groundwater samples were collected using the drilling method, and groundwater samples in the Quaternary aquifer were collected from a motor-pumped well for civil use. Electrical conductivity, $\mathrm{pH}$, and TDS field measurement of water samples were performed during sampling. Water samples were collected with $550 \mathrm{~mL}$ clean plastic 

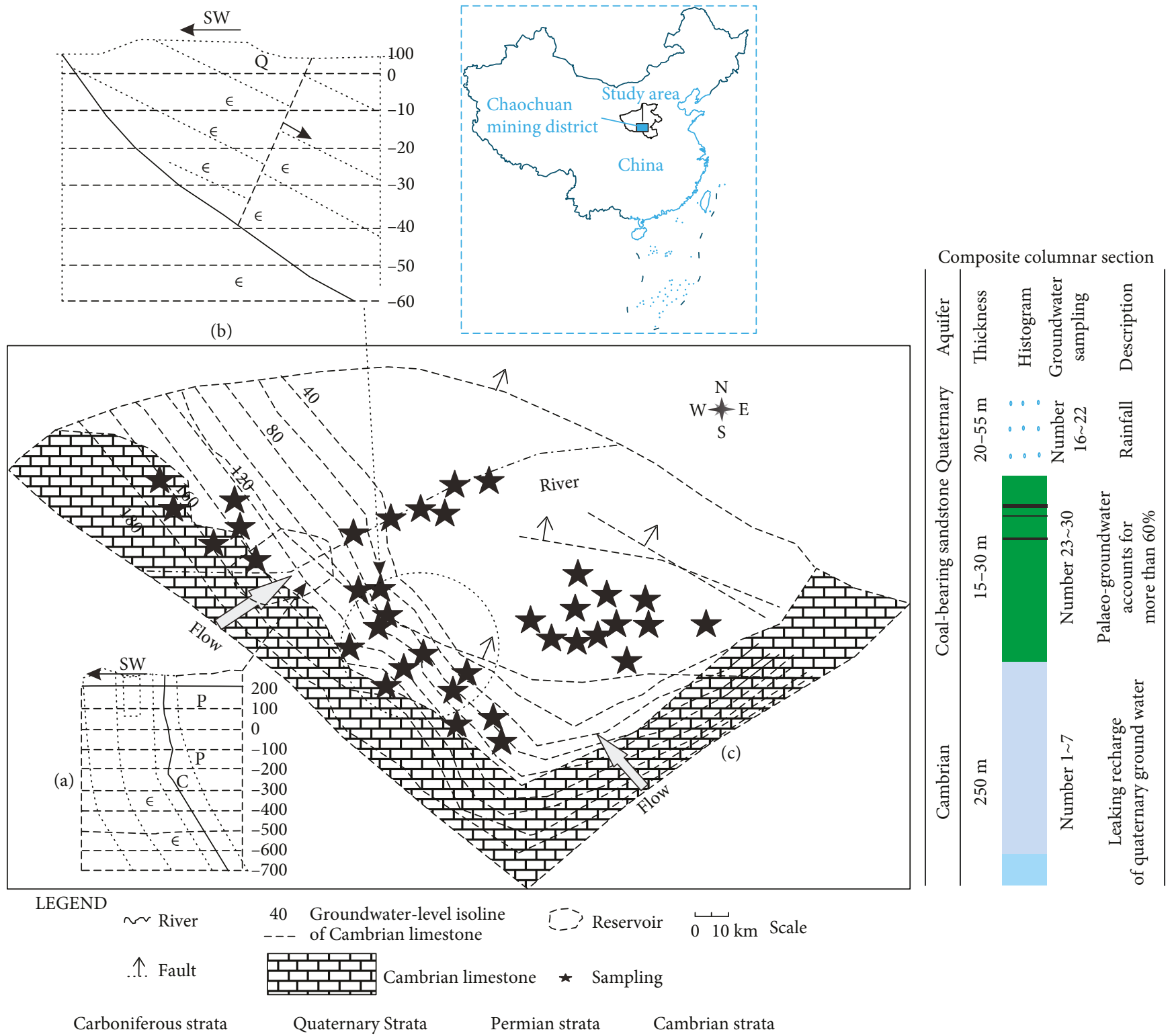

Figure 1: Hydrogeological map of the Chaochuan coal mining district in China. C: Carboniferous strata; Q: Quaternary strata; P: Permian strata; $\epsilon$ : Cambrian strata.

bottles to test isotopes and aqueous chemical ions. Samples were passed through $0.45 \mu \mathrm{m}$ precleaned membrane filters and were kept refrigerated at approximately $4^{\circ} \mathrm{C}$ before analyses. Relevant parameters of all water samples were analyzed, including TDS, $\mathrm{pH}, \mathrm{Ca}^{2+}, \mathrm{Mg}^{2+}, \mathrm{Na}^{+}, \mathrm{K}^{+}$, $\mathrm{HCO}_{3}{ }^{-}, \mathrm{SO}_{4}{ }^{2-}, \mathrm{Cl}^{-}, \delta^{18} \mathrm{O}, \delta^{2} \mathrm{H}, \delta^{3} \mathrm{H}$, and $\delta^{13} \mathrm{C}$. Table 1 shows the mean of analysis results. The hydrogen isotope test of water samples used the $\mathrm{Zn}$ reaction method, and the oxygen isotope test used the $\mathrm{O}-\mathrm{CO}_{2}$ balance method. MAT253 isotope mass spectrometer was applied. Test results are expressed in \%o in accordance with VSMOW standards. The test accuracies are expressed as $\pm 0.2 \%$ and $\pm 0.1 \%$. Radioactive tritium and ${ }^{14} \mathrm{C}$ content were tested with the low-background liquid scintillation counter Tri-Carb $3170 \mathrm{TR} / \mathrm{SL}$. Anion $\left(\mathrm{SO}_{4}{ }^{2-}, \mathrm{Cl}^{-}\right)$compositions of water samples were tested using the Dionex UltiMate 3000 with a relative error of $0.1 \% \cdot \mathrm{HCO}_{3}{ }^{-}$and $\mathrm{CO}_{3}{ }^{2-}$ were tested by double indicator neutralization titration. The method was titrated by acid distribution and indicated by different indicators. The concentration of $\mathrm{HCO}_{3}{ }^{-}$and $\mathrm{CO}_{3}{ }^{2-}$ was calculated from the dosage of $\mathrm{H}_{2} \mathrm{SO}_{4}$ standard solution. The cation $\left(\mathrm{Ca}^{2+}, \mathrm{Mg}^{2+}, \mathrm{Na}^{+}\right.$, and $\left.\mathrm{K}^{+}\right)$concentration of water samples was measured using the Hitachi Z5000 atomic absorption spectrophotometer.

3.2. Descriptive Statistics Analysis. The standard deviation of TDS, $\mathrm{Na}^{+}, \mathrm{Ca}^{2+}, \mathrm{SO}_{4}{ }^{2-}$, and $\mathrm{HCO}_{3}{ }^{-}$in water samples is greater than 60 , which reflects that the water quality characteristics obviously differ. Meanwhile, the standard deviation of $\delta^{18} \mathrm{O}, \delta^{2} \mathrm{H}$, and $\delta^{13} \mathrm{C}$ value in water samples is greater than $1 \%$, which indicates that the sources of groundwater vary (Table 2). Notably, the TDS median of the MIX group is 
ن

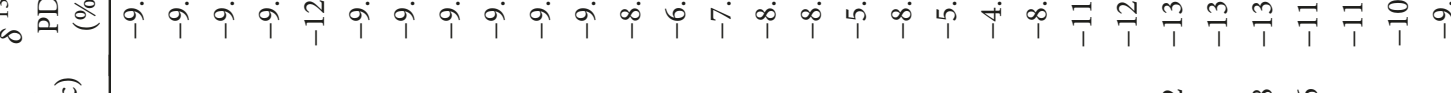
$\underset{్}{\exists}$

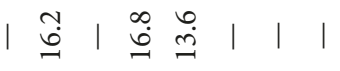

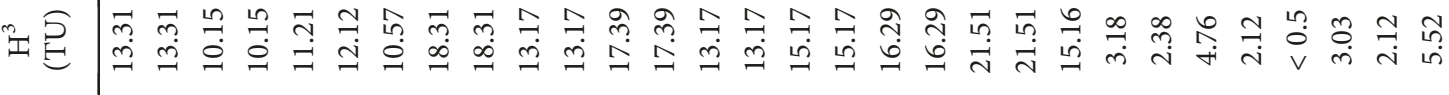

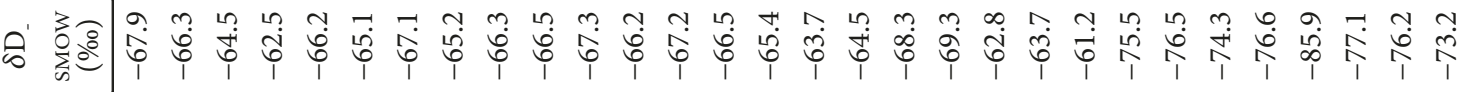

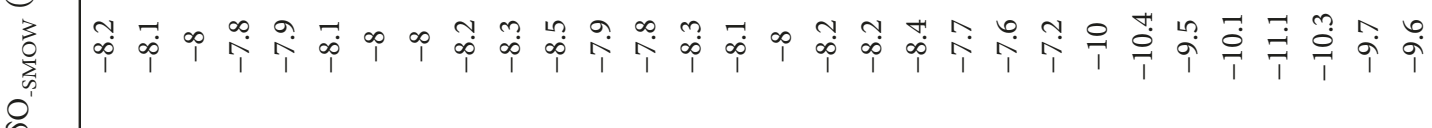
\&

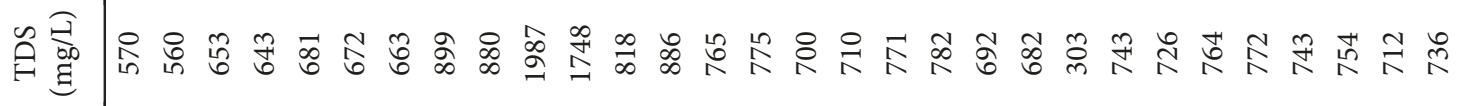
I. $\quad$ I

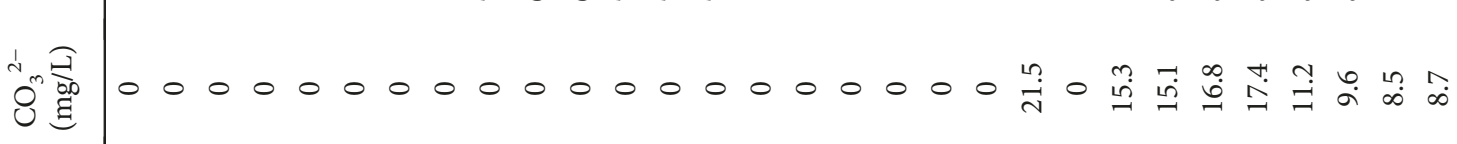

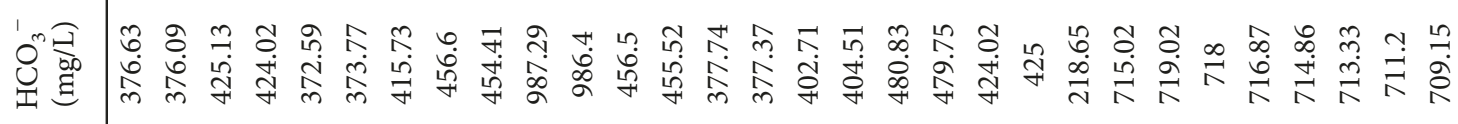

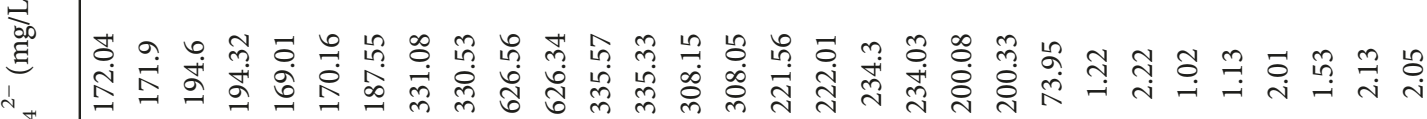
in

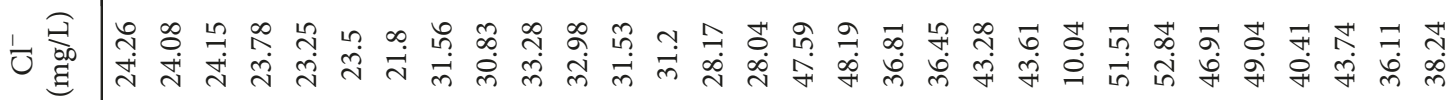

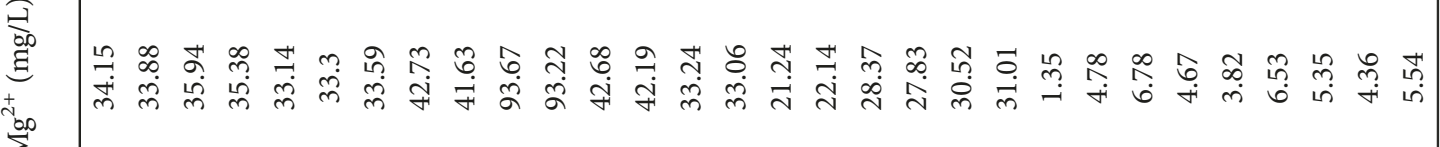

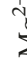

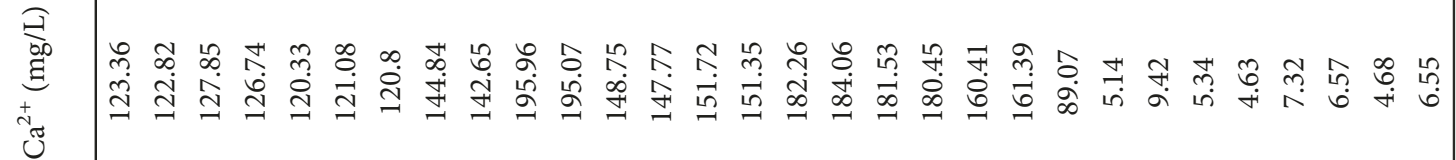

$+\frac{\theta}{0}$ o น

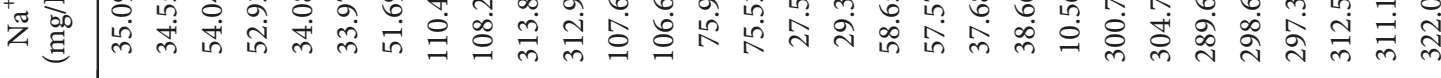

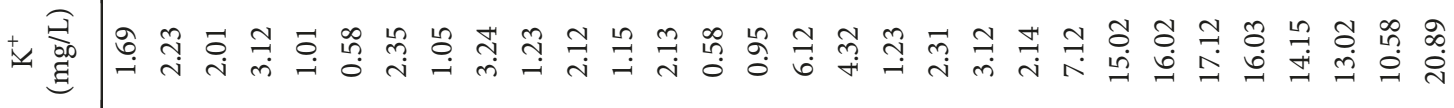

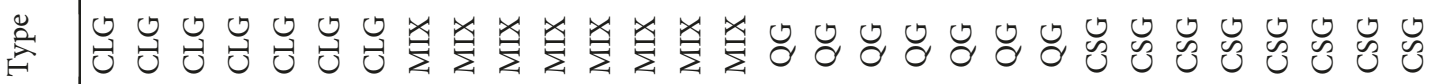
苛 壱

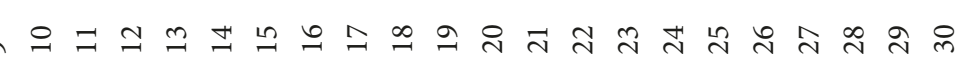




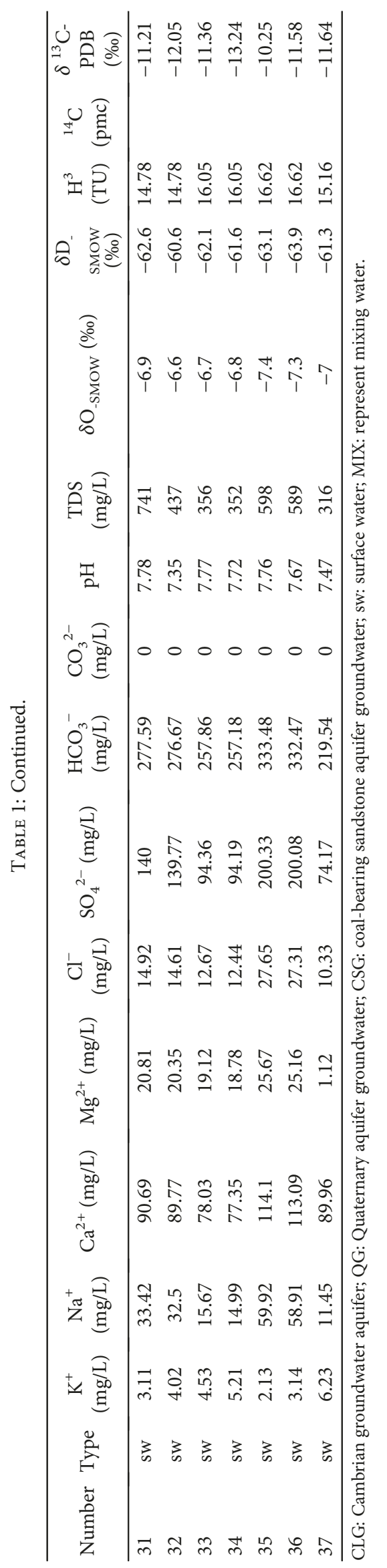




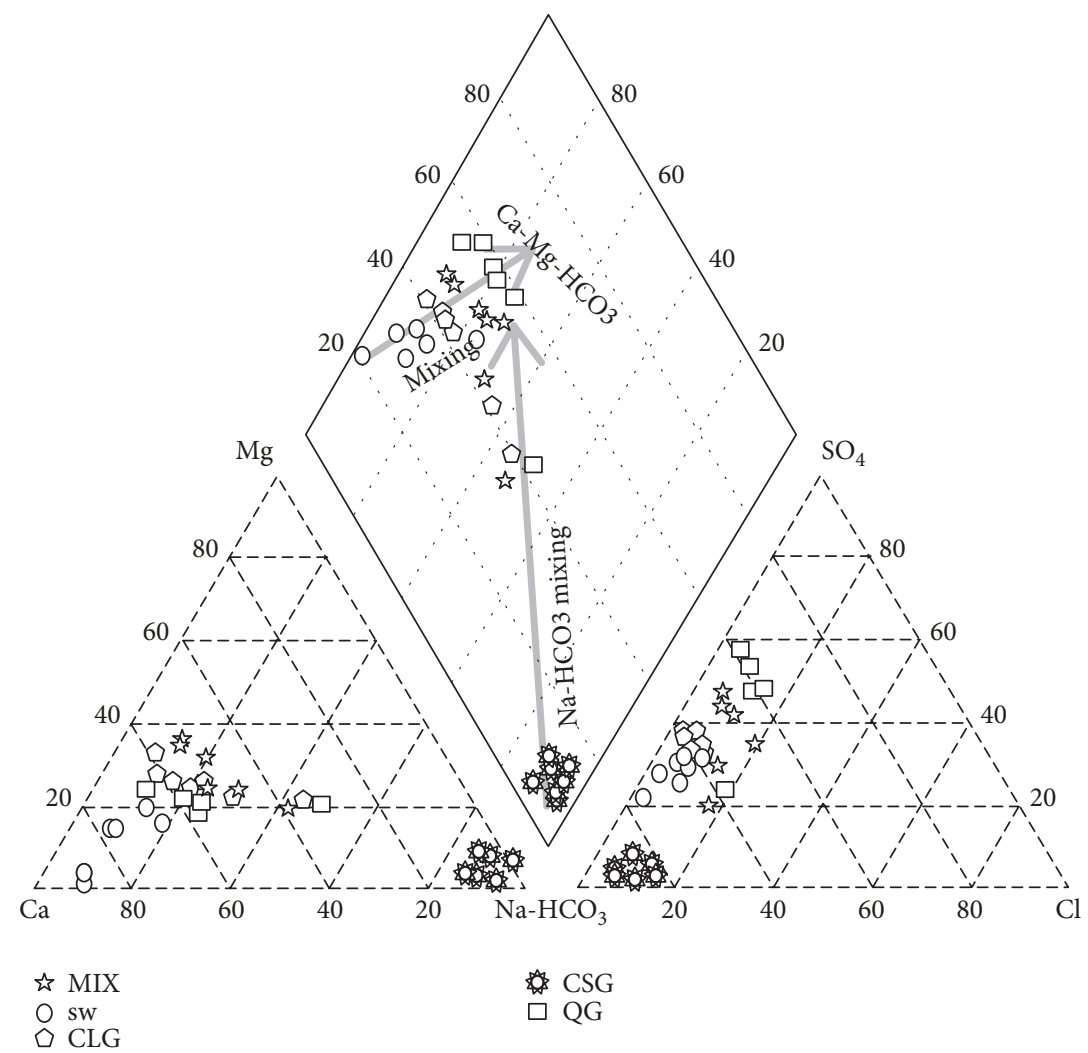

FIGURE 2: Piper trilinear diagram of the water samples. MIX: mixing water; CLG: Cambrian aquifer groundwater; QG: Quaternary aquifer groundwater; sw: surface water; CSG: coal-bearing sandstone aquifer groundwater.

TABle 2: Chemical composition descriptive statistics of water samples in the study area.

\begin{tabular}{lccccc}
\hline Component & $\begin{array}{c}\text { Total } \\
\text { sample }\end{array}$ & Min & Max & Mean & $\begin{array}{c}\text { Std. } \\
\text { deviation }\end{array}$ \\
\hline $\mathrm{K}^{+}(\mathrm{mg} / \mathrm{L})$ & 37 & 0.58 & 20.89 & 5.48 & 5.63 \\
$\mathrm{Na}^{+}(\mathrm{mg} / \mathrm{L})$ & 37 & 10.56 & 322.05 & 119.765 & 118.02 \\
$\mathrm{Ca}^{2+}(\mathrm{mg} / \mathrm{L})$ & 37 & 4.63 & 195.96 & 107.64 & 62.42 \\
$\mathrm{Mg}^{2+}(\mathrm{mg} / \mathrm{L})$ & 37 & 1.12 & 93.67 & 26.94 & 20.84 \\
$\mathrm{Cl}^{-}(\mathrm{mg} / \mathrm{L})$ & 37 & 10.04 & 52.84 & 31.27 & 12.09 \\
$\mathrm{SO}_{4}{ }^{2-}(\mathrm{mg} / \mathrm{L})$ & 37 & 1.02 & 626.56 & 183.88 & 151.96 \\
$\mathrm{HCO}_{3}{ }^{-}(\mathrm{mg} / \mathrm{L})$ & 37 & 218.65 & 987.29 & 481.71 & 197.96 \\
$\mathrm{CO}_{3}{ }^{2-}(\mathrm{mg} / \mathrm{L})$ & 37 & 0 & 21.50 & 3.35 & 6.36 \\
$\mathrm{pH}^{\mathrm{TDS}}(\mathrm{mg} / \mathrm{L})$ & 37 & 6.62 & 9.85 & 7.55 & 0.65 \\
$\delta^{18} \mathrm{O}(\% \circ-\mathrm{SMOW})$ & 37 & 303.00 & 1987.0 & 734.56 & 314.18 \\
$\delta \mathrm{D}(\% 0-\mathrm{SMOW})$ & 37 & -85.90 & -60.60 & -67.41 & 5.72 \\
$\mathrm{H}^{3}(\mathrm{TU})$ & 36 & 2.12 & 21.51 & 12.75 & 5.41 \\
${ }^{14} \mathrm{C}(\mathrm{pmc})$ & 3 & 13.60 & 16.80 & 15.53 & 1.70 \\
$\delta{ }^{13} \mathrm{C}-\mathrm{PDB}(\%)$ & 37 & -13.98 & -4.61 & -9.95 & 2.19 \\
\hline
\end{tabular}

significantly higher than that of the others and reflects a pollution characteristic. However, the concentrations of $\mathrm{Na}^{+}, \mathrm{Ca}^{2+}$, and $\mathrm{HCO}_{3}{ }^{-}$of the CSG group reflect a cation exchange characteristic.
3.3. Mixing Ratio Analysis. The $\mathrm{H}$ and $\mathrm{O}$ stable isotopes of groundwater would not change during their interaction with rocks under low temperature $\left(<60^{\circ} \mathrm{C}\right)$. Thus, the mixing ratio could be calculated by a linear mixing ratio calculation model of two or three end members. The model $(n=3)$ is as follows:

$$
\begin{aligned}
\delta \mathrm{D} & =X_{1}(\delta \mathrm{D})_{1}+\cdots+(\delta \mathrm{D})_{n}, \\
\delta^{18} \mathrm{O} & =X_{1}\left(\delta^{18} \mathrm{O}\right)_{1}+\cdots+\left(\delta^{18} \mathrm{O}\right)_{n}, \\
X_{1}+X_{2}+\cdots+X_{n} & =1,
\end{aligned}
$$

where $\delta \mathrm{D}$ and $\delta^{18} \mathrm{O}$ are the compositions of mixed $\mathrm{H}$ and $\mathrm{O}$ stable isotopes, respectively, and $(\delta \mathrm{D})_{1}, \ldots,(\delta \mathrm{D})_{n}$ and $\left(\delta^{18} \mathrm{O}\right)_{1}, \ldots,\left(\delta^{18} \mathrm{O}\right)_{n}$ are the compositions of $\mathrm{H}$ and $\mathrm{O}$ stable isotopes, respectively, of different end members. $X_{1}$, $X_{2}, \ldots, X_{n}$ denote the mixing ratios of different end members. The groundwater tracing results in the study area show that rainfall-penetrated groundwater and evaporated groundwater (Quaternary groundwater) and "palaeogroundwater" (coalbed sandstone groundwater) exhibit different $\mathrm{H}$ and $\mathrm{O}$ stable isotope characteristics. Therefore, the two types of groundwater can be used as a mixing end member directly.

\section{Results and Discussion}

The two major hydrochemical types of groundwater in the study area are (1) $\mathrm{Ca}-\mathrm{Mg}-\mathrm{HCO}_{3}$ and (2) $\mathrm{Na}-\mathrm{HCO}_{3}$. The 


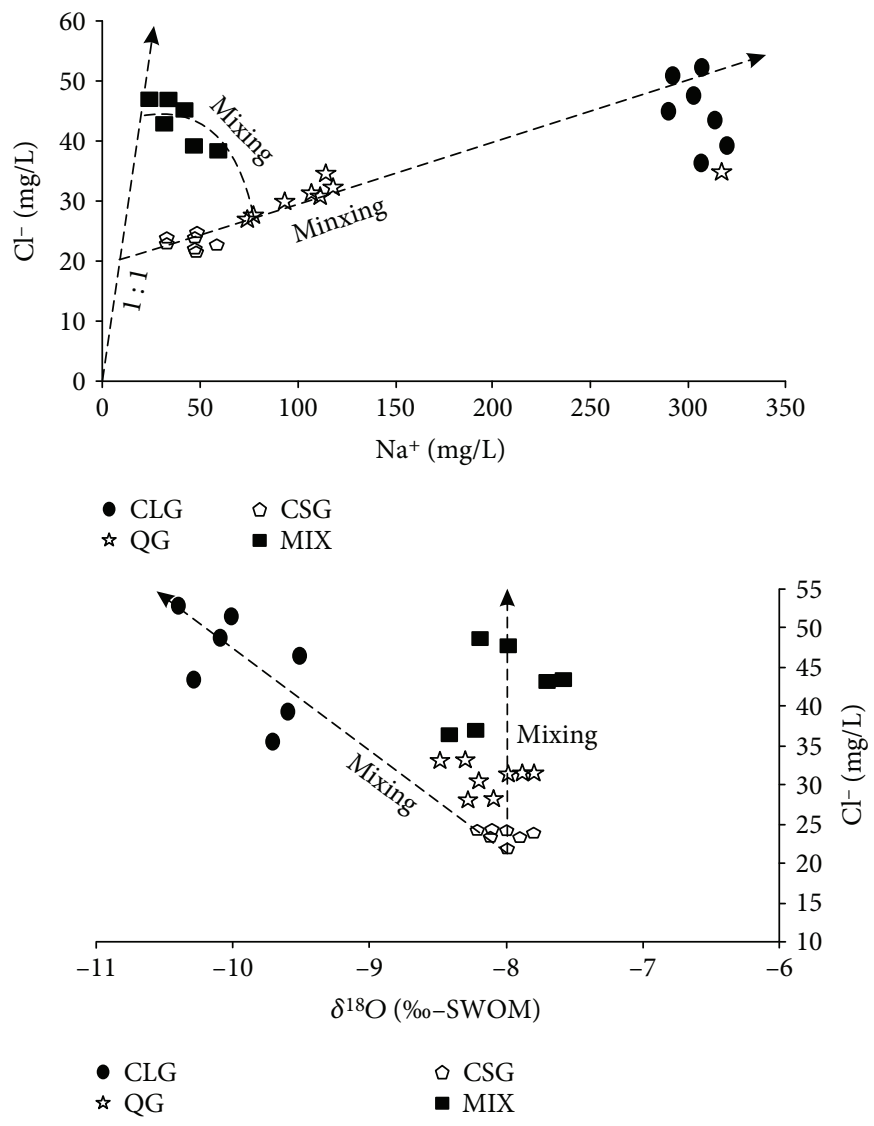

FIGURE 3: $\mathrm{Na}^{+} / \mathrm{Cl}^{-}$and $\mathrm{Cl}-\delta^{18} \mathrm{O}$ diagrams of the water samples. MIX: mixing water; CLG: Cambrian aquifer groundwater; QG: Quaternary aquifer groundwater; sw: surface water; CSG: coal-bearing sandstone aquifer groundwater.

main hydrochemical type of sandstone groundwater in the coalbed is $\mathrm{Na}-\mathrm{HCO}_{3}$, and the positive ion concentrations are $\mathrm{Na}^{+}>\mathrm{Ca}^{2+}>\mathrm{Mg}^{2+}$ (Figure 2). The major hydrochemical type of Cambrian limestone groundwater and Quaternary groundwater is $\mathrm{Ca}-\mathrm{Mg}-\mathrm{HCO}_{3}$. $\mathrm{Ca}-\mathrm{Mg}-\mathrm{HCO}_{3}$ is mainly mixed by Cambrian limestone groundwater and Quaternary groundwater, deviates significantly from the $\mathrm{Na}^{+} / \mathrm{Cl}^{-}=1: 1$ line, and falls on the same fitting line with Cambrian limestone groundwater and mixed drilling groundwater (Figure 3). $\mathrm{Cl}-\delta^{18} \mathrm{O}$ reveals that an appropriate amount of sandstone groundwater in the coalbed participates in the mixing along the groundwater runoff.

Quaternary groundwater and Cambrian limestone groundwater samples mostly distribute along the evaporation line; this distribution implies that karst water and Quaternary groundwater have the same source in the study area and are mainly recharged by penetration of surface water (Figure 4). However, some Quaternary groundwater, Cambrian limestone groundwater, and coalbed sandstone groundwater samples deviate from the evaporation line greatly, and this deviation indicates remarkable mixing with "palaeo-groundwater." The ${ }^{3} \mathrm{H}$ value of one coalbed sandstone groundwater sample is smaller than 0.5 , which is smaller than the test value of the instrument. The ${ }^{14} \mathrm{C}$ content is $13.6 \mathrm{pmc}$, which indicates that this sample may be the last one recharged by rainfall in the ice stage and can be used as the end member of palaeo-groundwater.

The $\delta \mathrm{D}$ and $\delta^{18} \mathrm{O}$ values of Quaternary groundwater and Cambrian limestone groundwater increase with the increase in TDS (Figure 5). TDS is mixed with the original aquifer groundwater along the runoff direction, thereby decreasing the $\delta \mathrm{D}$ and $\delta^{18} \mathrm{O}$ values. However, TDS along the runoff direction increases. In coalbed sandstone groundwater, $\delta^{13} \mathrm{C}$ decreases with the increase in $\mathrm{CO}_{3}{ }^{2-}+\mathrm{HCO}_{3}{ }^{-}$(line 3 in Figure 6). This condition indicates kinetic fractionation of groundwater in biodegradation of organic matters. $\delta^{13} \mathrm{C}$ increases with the increase in $\mathrm{CO}_{3}{ }^{2-}+\mathrm{HCO}_{3}{ }^{-}$in Cambrian limestone groundwater, and this condition indicates that organic matters produce methane due to methanogens (line 1 in Figure 6). For Quaternary groundwater, $\delta^{13} \mathrm{C}$ decreases with the increase in $\mathrm{CO}_{3}{ }^{2-}+\mathrm{HCO}_{3}{ }^{-}$(line 2 in Figure 6).

Groundwater samples from different aquifers in the study area are drawn in the $\delta^{18} \mathrm{O}-\delta \mathrm{D}$ scatter diagram in accordance with the $\delta$ value ( $\delta \mathrm{D}$ and $\delta^{18} \mathrm{O}$ ) (Figure 7$) . \triangle \mathrm{AB}$ $\mathrm{C}$ is determined in accordance with the distribution features of water sample points. The results of the established linear groundwater-mixing ratio calculation model and groundwater recharge process and tracing qualitatively show that $\mathrm{A}$ in $\triangle \mathrm{ABC}$ represents palaeo-groundwater with low proportion, $\mathrm{B}$ stands for rainfall-penetrated groundwater free from 


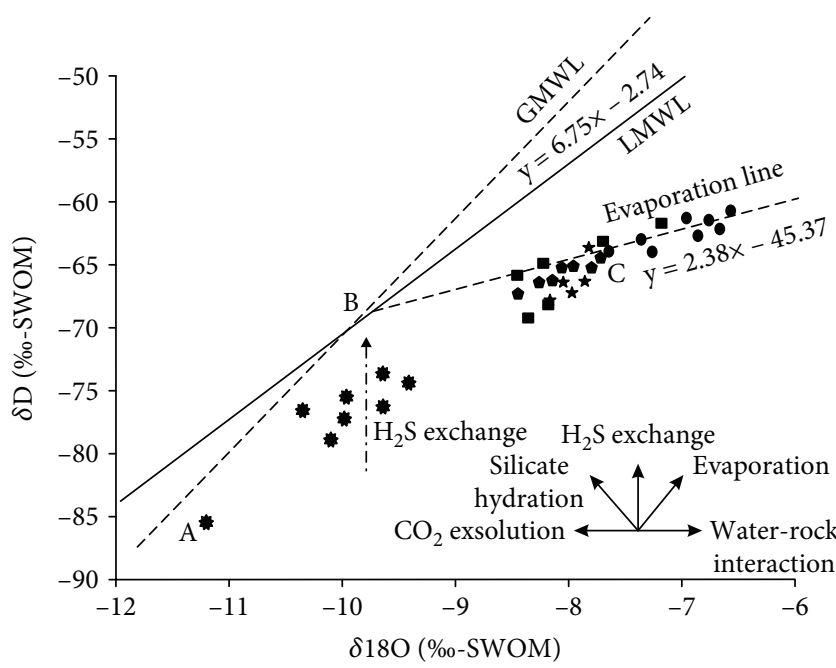

MIX--mixing water CLG--Cambrian aquifer groundwater QG--Quaternary aquifer groundwater sw--surface water CSG--Coal bearing sandstone aquifer groundwater

$\begin{array}{ll}\star \mathrm{MIX} & \text { CSG } \\ \text { - } \mathrm{sW} & \mathrm{CLG}\end{array}$

FIGURE 4: $\delta \mathrm{D}-\delta^{18} \mathrm{O}$ plot showing the stable isotope composition of water in the study area, which indicates the recharge sources. MIX: mixing water; CLG: Cambrian aquifer groundwater; QG: Quaternary aquifer groundwater; sw: surface water; CSG: coalbearing sandstone aquifer groundwater.

evaporation, and $\mathrm{C}$ is Quaternary groundwater that has experienced surface evaporation and has high $\delta$. The $\delta^{18} \mathrm{O}-\delta \mathrm{D}$ scatter diagram of groundwater shows that the Quaternary groundwater and Cambrian limestone groundwater are close to the intersection end of the "BC" and " $A C$ " lines. Penetration water in the aquifer due to evaporation takes the dominant advantages. Coalbed sandstone groundwater is close to the intersection end of the "BA" and "AC" lines, and this condition shows remarkable mixing with palaeo-groundwater.

As shown in Figure 8, $\mathrm{HCO}_{3}^{-}$and $\mathrm{Cl}^{-}$exhibit a linear relationship with the mixing ratio, whereas $\mathrm{Na}^{+}, \mathrm{Ca}^{2+}$, and $\mathrm{SO}_{4}{ }^{2-}$ show certain degrees of curvature. This condition reflects that $\mathrm{HCO}_{3}{ }^{-}$and $\mathrm{Cl}^{-}$can be used as conservative tracing ions to study the mixing process of groundwater. From the calculation results, coalbed sandstone groundwater is found to account for more than $60 \%$. On the contrary, the deep limestone groundwater accounts for less than $20 \%$, which is close to that of the Quaternary groundwater. This finding demonstrates that deep limestone groundwater mainly comes from the leaking recharge of Quaternary groundwater, which is considered "modern" rainfall recharge.

\section{Conclusion}

In this study, aquifer groundwater, local rainfall, and surface water samples, which exert important impacts on coal exploitation in a typical coalfield (Chaochuan Coal Mine),
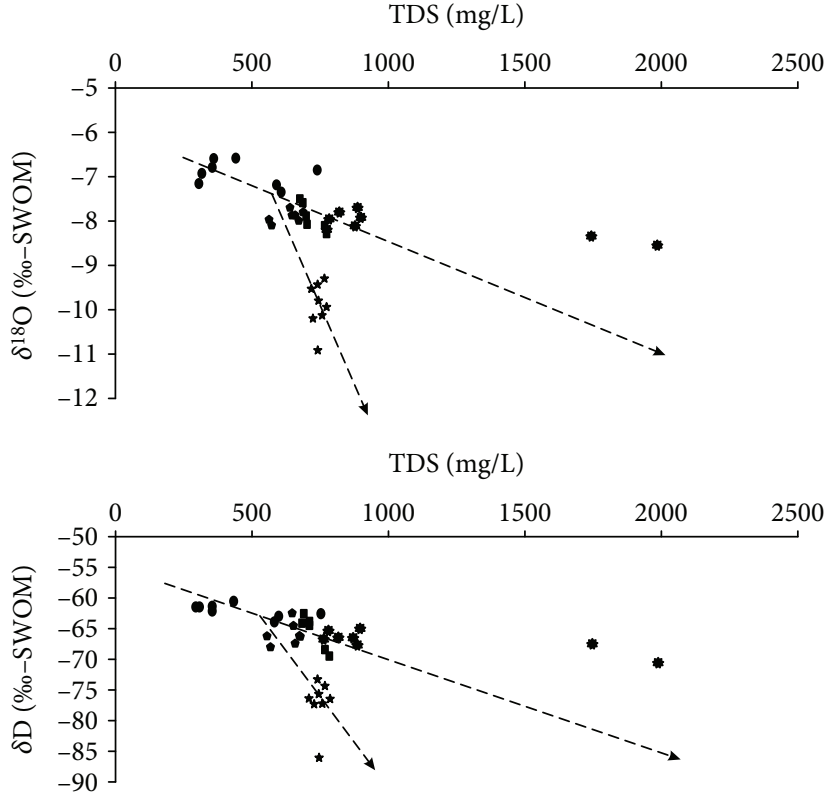

MIX--mixing water CLG--Cambrian aquifer groundwater QG--Quaternary aquifer groundwater sw--surface water CSG--Coal bearing sandstone aquifer groundwater

$\begin{array}{ll}\text { ^ } \mathrm{MIX} & \text { - } \mathrm{CSG} \\ \text { - } \mathrm{sW} & \text { - } \mathrm{QLG}\end{array}$

FIGURE 5: $\delta \mathrm{D}-\mathrm{TDS}$ and $\delta^{18} \mathrm{O}-\mathrm{TDS}$ plots showing the increase in oxyhydrogen stable isotope ( $\delta$ value) of groundwater samples with the change in TDS. MIX: mixing water; CLG: Cambrian aquifer groundwater; QG: Quaternary aquifer groundwater; sw: surface water; CSG: coal-bearing sandstone aquifer groundwater.

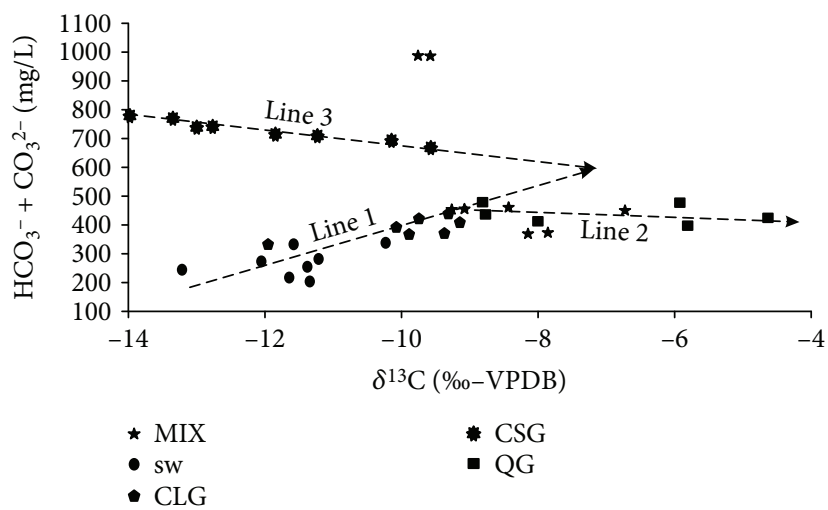

Figure 6: $\delta{ }^{13} \mathrm{C}$ versus $\mathrm{CO}_{3}{ }^{2-}+\mathrm{HCO}_{3}{ }^{-}$diagram of the water samples. MIX: mixing water; CLG: Cambrian aquifer groundwater; QG: Quaternary aquifer groundwater; sw: surface water; CSG: coal-bearing sandstone aquifer groundwater.

were collected at different seasons. The following conclusions were drawn:

(1) In the study area, long-term water filling after exploitation of aquifer occurs, which may destroy the original groundwater circulation of the aquifer. 


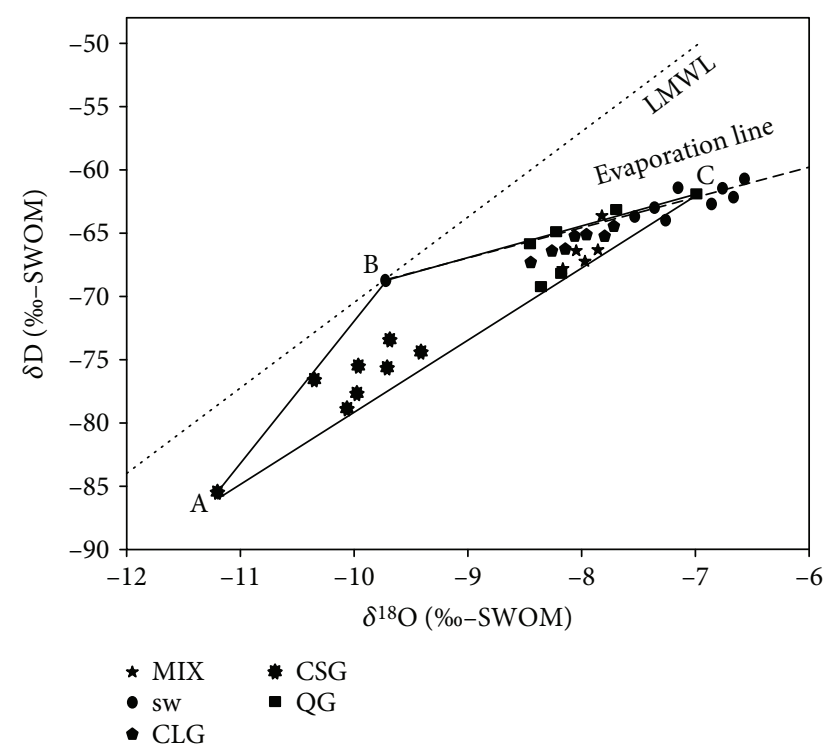

Figure $7: \delta \mathrm{D}-\delta^{18} \mathrm{O}$ plot showing the mixing process of groundwater. MIX: mixing water; CLG: Cambrian aquifer groundwater; QG: Quaternary aquifer groundwater; sw: surface water; CSG: coal-bearing sandstone aquifer groundwater.

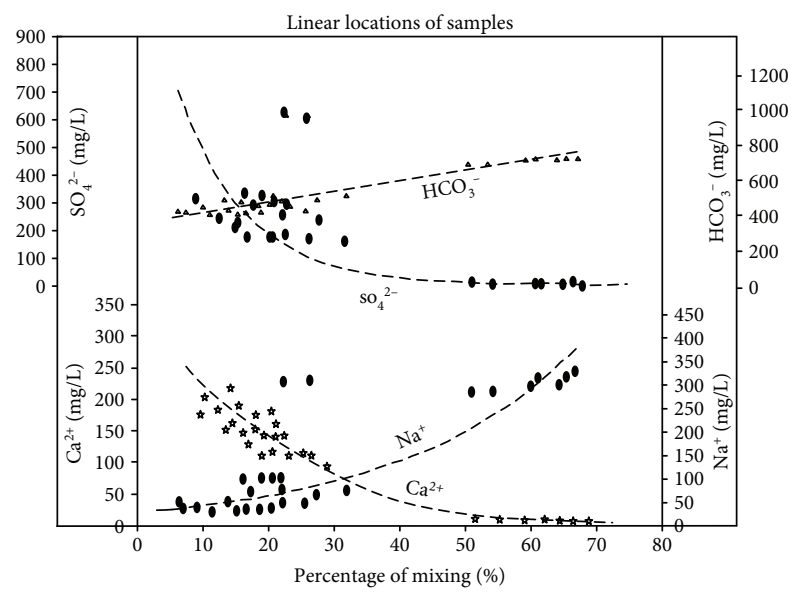

FIGURE 8: Plot of mixing ratio versus $\mathrm{Na}^{+}, \mathrm{Ca}^{2+}, \mathrm{HCO}_{3}{ }^{-}$, and $\mathrm{SO}_{4}{ }^{2-}$ showing the use of conservative tracing ions in studying the mixing process of groundwater.

Hydraulic alteration in the recharge area accelerates, and surface water is recharged into the aquifer in the study area.

(2) In the main recharging aquifer in the study area, rainfall penetration is the main source of Cambrian limestone groundwater in the north limestone outcropped region, and surface water penetration is the main source of Quaternary groundwater. Coalbed sandstone groundwater mainly comes from the mixture of palaeo-groundwater and Quaternary groundwater. Cambrian limestone groundwater, coalbed sandstone groundwater, and Quaternary groundwater present a high potential to be mixed together.
(3) Water sources during coal mining can be deduced from the quantitative perspective in accordance with the dynamic changes in stable isotope compositions and the variation in the trend of the linear member mixing ratio at an effluent sampling site under the shaft. Specific countermeasures against water inrush accidents should be taken to protect groundwater resources effectively. This model is applicable to water disaster control in North China-type coalfields after proper modifications. The research conclusions can provide important references for water disaster control in other coalfields.

\section{Data Availability}

The data used to support the findings of this study are available from the corresponding author upon request.

\section{Conflicts of Interest}

The authors declare that they have no conflicts of interest.

\section{Acknowledgments}

This work was financially supported by the National Natural Science Foundation of China (Grant 41672240); Henan Province Technical Innovation Guidance Special (Grant 182107000019); Science and Technology Key Research Project of the Education Department of Henan, China (Grants 13A170313 and 14A510022); China Postdoctoral Science Foundation (2017M612395); Innovation Scientists and Technicians Troop Construction Projects of Henan Province (Grant CXTD2016053); Henan Province's Technological Innovation Team of Colleges and Universities (Grant 15IRTSTHN027); Fundamental Research Funds for the Universities of Henan Province (NSFRF1611); and Scientists and Technicians Projects of Henan Province (Grant 172107000004).

\section{References}

[1] A. Akerman, F. Poitrasson, P. Oliva, S. Audry, J. Prunier, and J. J. Braun, "The isotopic fingerprint of Fe cycling in an equatorial soil-plant-water system: the Nsimi watershed, South Cameroon," Chemical Geology, vol. 385, pp. 104-116, 2014.

[2] A. Ben Moussa, H. Mzali, K. Zouari, and H. Hezzi, "Hydrochemical and isotopic assessment of groundwater quality in the Quaternary shallow aquifer, Tazoghrane region, north-eastern Tunisia," Quaternary International, vol. 338, pp. 51-58, 2014.

[3] C. A. Delconte, E. Sacchi, E. Racchetti, M. Bartoli, J. Mas-Pla, and V. Re, "Nitrogen inputs to a river course in a heavily impacted watershed: a combined hydrochemical and isotopic evaluation (Oglio River Basin, N Italy)," Science of the Total Environment, vol. 466-467, pp. 924-938, 2014.

[4] D. Zhang, X. D. Li, Z. Q. Zhao, and C. Q. Liu, "Using dual isotopic data to track the sources and behaviors of dissolved sulfate in the western North China Plain," Applied Geochemistry, vol. 52, pp. 43-56, 2015. 
[5] D. M. Kim, S. T. Yun, M. J. Kwon, B. Mayer, and K. H. Kim, "Assessing redox zones and seawater intrusion in a coastal aquifer in South Korea using hydrogeological, chemical and isotopic approaches," Chemical Geology, vol. 390, pp. 119-134, 2014.

[6] D. M. Han, X. F. Song, M. J. Currell, and M. Tsujimura, "Using chlorofluorocarbons (CFCs) and tritium to improve conceptual model of groundwater flow in the south coast aquifers of Laizhou Bay, China," Hydrological Processes, vol. 26, no. 23, pp. 3614-3629, 2012.

[7] G. Martinelli, A. Chahoud, A. Dadomo, and A. Fava, "Isotopic features of Emilia-Romagna region (North Italy) groundwaters: environmental and climatological implications," Journal of Hydrology, vol. 519, pp. 1928-1938, 2014.

[8] H. el Mejri, A. Ben Moussa, and K. Zouari, "The use of hydrochemical and environmental isotopic tracers to understand the functioning of the aquifer system in the Bou Hafna and Haffouz regions, Central Tunisia," Quaternary International, vol. 338, pp. 88-98, 2014.

[9] I. Matiatos, A. Alexopoulos, and A. Godelitsas, "Multivariate statistical analysis of the hydrogeochemical and isotopic composition of the groundwater resources in northeastern Peloponnesus (Greece)," Science of the Total Environment, vol. 476-477, pp. 577-590, 2014.

[10] J. Sültenfu $\beta$, R. Purtschert, and J. F. Führböter, "Age structure and recharge conditions of a coastal aquifer (northern Germany) investigated with ${ }^{39} \mathrm{Ar},{ }^{14} \mathrm{C},{ }^{3} \mathrm{H}$, He isotopes and Ne," Hydrogeology Journal, vol. 19, no. 1, pp. 221-236, 2011.

[11] L. J. Lambán, J. Jódar, E. Custodio, A. Soler, G. Sapriza, and R. Soto, "Isotopic and hydrogeochemical characterization of high-altitude karst aquifers in complex geological settings: the Ordesa and Monte Perdido National Park (Northern Spain) case study," Science of the Total Environment, vol. 506-507, pp. 466-479, 2015.

[12] J. M. Heikoop, T. M. Johnson, K. H. Birdsell et al., "Isotopic evidence for reduction of anthropogenic hexavalent chromium in Los Alamos National Laboratory groundwater," Chemical Geology, vol. 373, pp. 1-9, 2014.

[13] N. Mohammed, H. Celle-Jeanton, F. Huneau et al., "Isotopic and geochemical identification of main groundwater supply sources to an alluvial aquifer, the Allier River valley (France)," Journal of Hydrology, vol. 508, pp. 181-196, 2014.

[14] T. Hosono, O. Lorphensriand, S.-i. Onodera et al., "Different isotopic evolutionary trends of $\delta 34 \mathrm{~S}$ and $\delta 18 \mathrm{O}$ compositions of dissolved sulfate in an anaerobic deltaic aquifer system," Applied Geochemistry, vol. 46, pp. 30-42, 2014.

[15] W. Sanford, "Calibration of models using groundwater age," Hydrogeology Journal, vol. 19, no. 1, pp. 13-16, 2011.

[16] J. Chen, X. Liu, C. Wang et al., "Isotopic constraints on the origin of groundwater in the Ordos Basin of northern China," Environmental Earth Sciences, vol. 66, no. 2, pp. 505-517, 2012.

[17] X. Y. Liu, J. S. Chen, X. X. Sun, and Z. G. Su, "Study on soil water movement during rainfall infiltration using stable isotopic tracing method," Nuclear Science and Techniques, vol. 22, pp. 251-256, 2011.

[18] X. Xu, H. Guan, and Z. Deng, "Isotopic composition of throughfall in pine plantation and native eucalyptus forest in South Australia," Journal of Hydrology, vol. 514, pp. 150-157, 2014.
[19] Y. Zhang, S. Ye, and J. Wu, "A modified global model for predicting the tritium distribution in precipitation, 1960-2005," Hydrological Processes, vol. 25, no. 15, pp. 2379-2392, 2011.

[20] C. M. Ordens, A. D. Werner, V. E. A. Post, J. L. Hutson, C. T. Simmons, and B. M. Irvine, "Groundwater recharge to a sedimentary aquifer in the topographically closed Uley South Basin, South Australia," Hydrogeology Journal, vol. 20, no. 1, pp. 61-72, 2012.

[21] T. Ayenew, S. Kebede, and T. Alemyahu, "Environmental isotopes and hydrochemical study applied to surface water and groundwater interaction in the Awash River basin," Hydrological Processes, vol. 22, no. 10, pp. 1548-1563, 2008.

[22] E. S. Lima, S. M. G. Montenegro, and A. A. Montenegro, "Environmental isotopes and the analysis of the origin of groundwater salinity in the Cabo Aquifer in Recife coastal plain, Pernambuco, Brazil," in Proceedings of the IV South American Symposium on Isotope Geology, Salvador, BA, Brazil, 2009.

[23] A. Vengosh, S. Hening, J. Ganor et al., "New isotopic evidence for the origin of groundwater from the Nubian sandstone aquifer in the Negev, Israel," Applied Geochemistry, vol. 22, no. 5, pp. 1052-1073, 2007.

[24] A. Murad, "Evolution of isotopic compositions in groundwater of the area between the Gulf of Oman and the Arabian Gulf," Chinese Journal of Geochemistry, vol. 29, no. 2, pp. 152-156, 2010. 

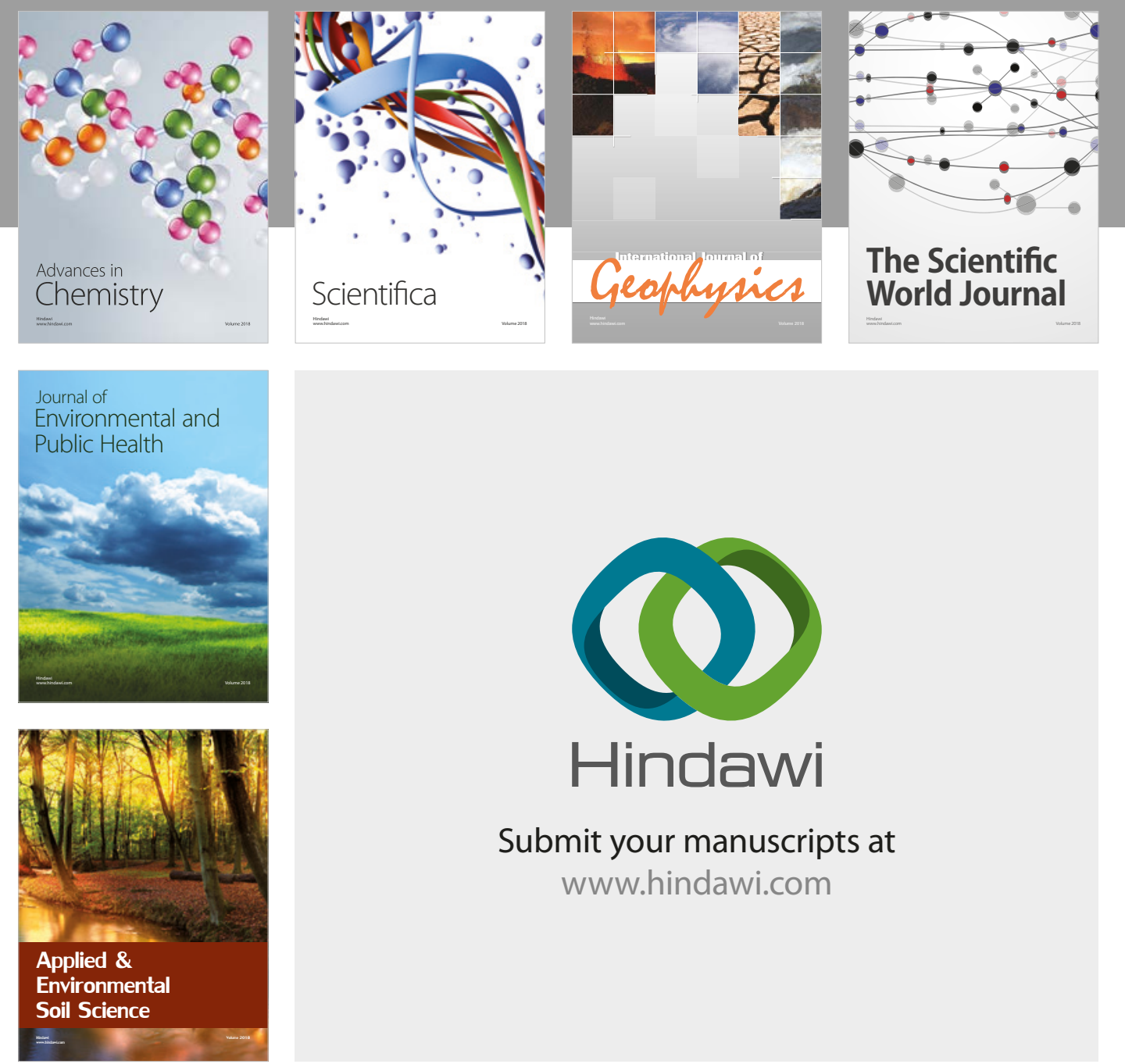

The Scientific

\section{World Journal}
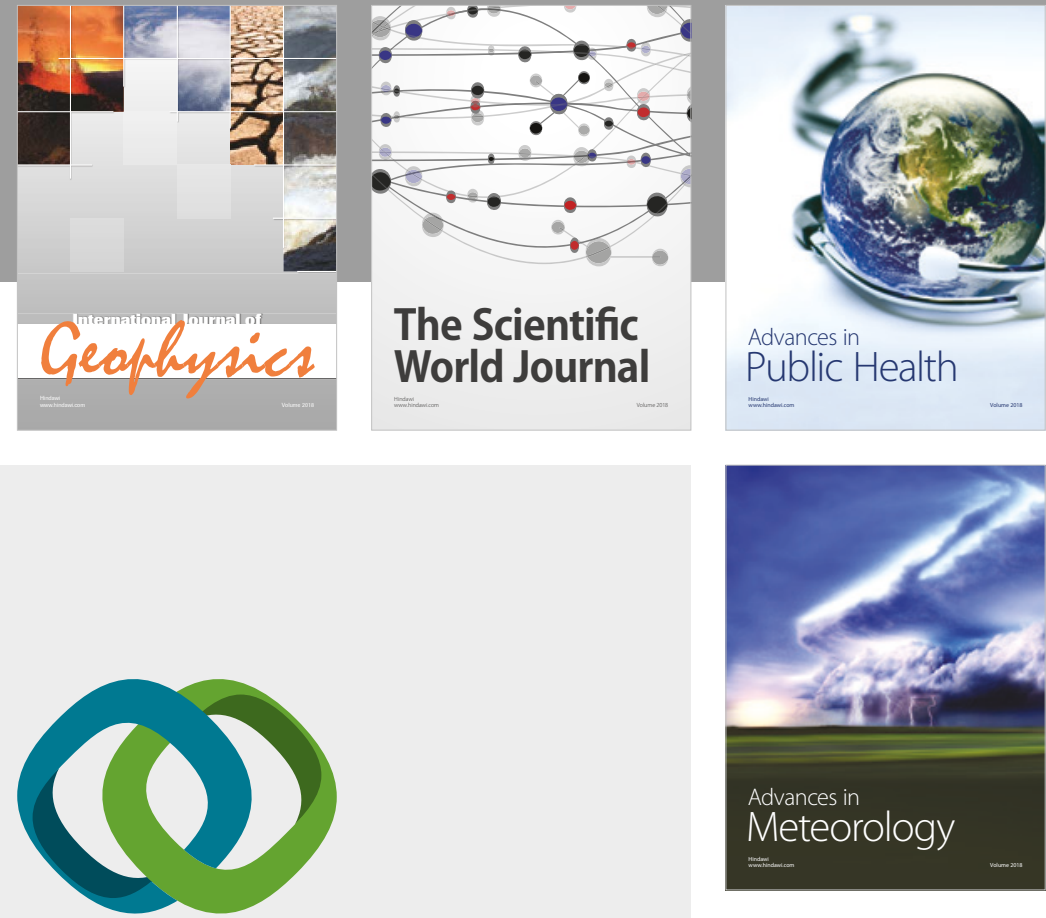

Advan

Public Health

\section{Hindawi}

Submit your manuscripts at

www.hindawi.com
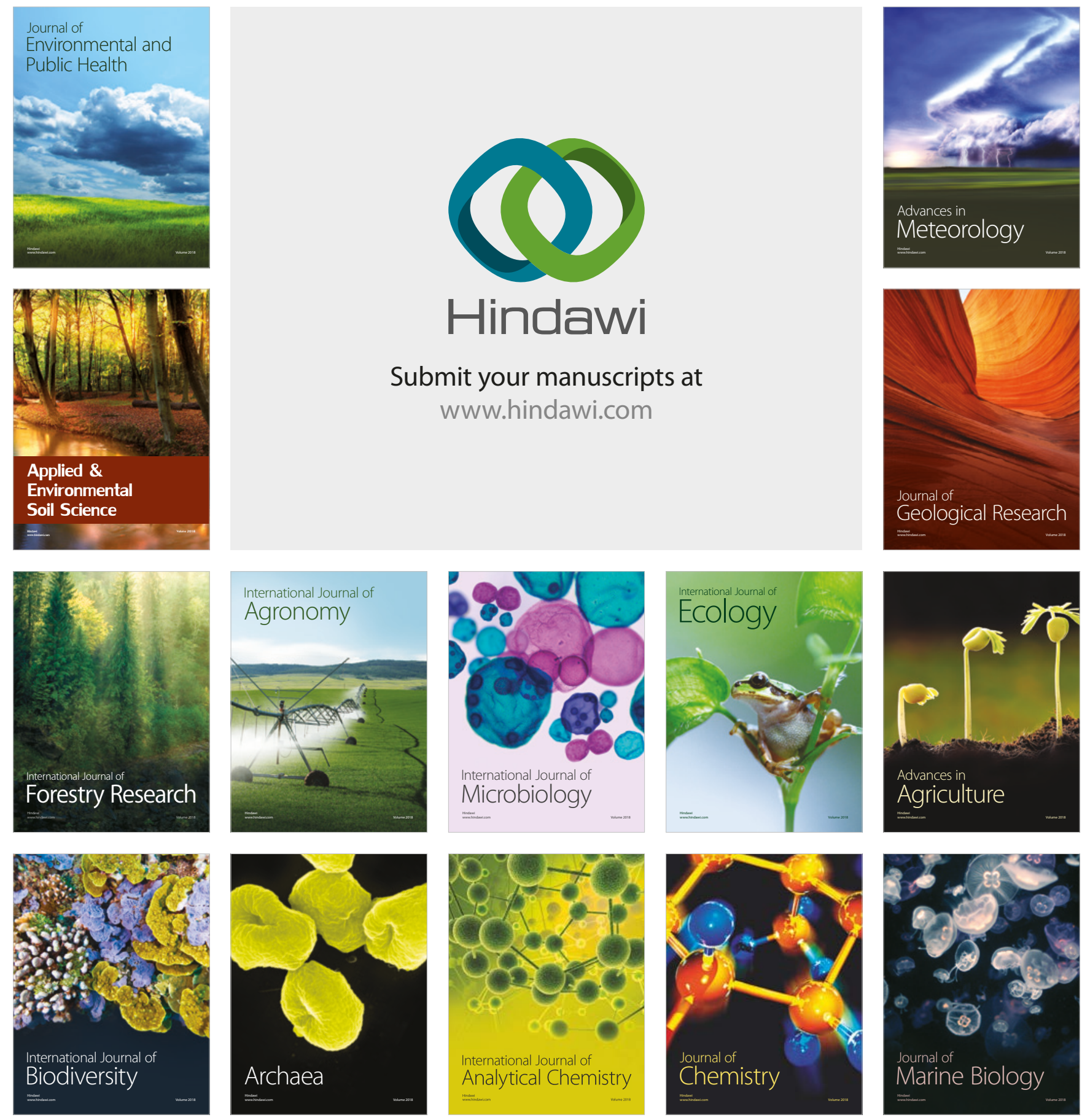